\title{
Visible bigeminal pulses with tortuous common carotid artery
}

\author{
Ryohei Ono (1), ${ }^{1}$ Kiyoshi Shikino (ㄷ, ${ }^{2}$ Yoshio Kobayashi ${ }^{1}$
}

${ }^{1}$ Department of Cardiovascular Medicine, Chiba University Graduate School of Medicine, Chiba, Japan

${ }^{2}$ Department of General Medicine, Chiba University Hospital, Chiba, Japan

\section{Correspondence to}

Dr Ryohei Ono;

ryohei_ono_0820@yahoo.co.jp

Accepted 1 April 2021

\section{DESCRIPTION}

An 84-year-old woman with a history of hypertension, diabetes mellitus, dyslipidaemia and aortic stenosis (AS) was referred to our hospital for transcatheter aortic valve implantation (TAVI). She occasionally recognised dyspnoea on exertion for the last 2 years, but she had no symptoms of chest pain or faintness. Physical examination revealed a pulsatile mass, bigeminal pulses with pulsatile vessels at the base of the right neck, prominent pulsations at the middle, and ejection systolic murmur on auscultation (video 1). Transthoracic echocardiography showed global left ventricular hypertrophy and severe AS but no aortic regurgitation (AR), tricuspid regurgitation (TR), nor ventricular outflow tract obstruction. Preoperative contrast CT angiography revealed diffuse calcified vessels and a tortuous right common carotid artery (CCA) (figure 1). The patient underwent TAVI, and AS improved after the procedure; however, the bigeminal pulses remained postoperatively. We finally diagnosed the bigeminal pulses caused not by AS but by the tortuous carotid artery. She was relieved of dyspnoea after the operation.

Possible differential diagnoses of pulsatile neck vessels include pulsus bisferiens of hypertrophic obstructive cardiomyopathy, pulsus parvus and tardus of AS, dancing carotid of AR, c-v waves of TR (Lancisi sign), cannon a wave of third-degree heart block, and bigeminal pulses of tortuous carotid artery or aortic aneurysms. ${ }^{1}$ Tortuosity of the common carotid artery is seen especially in women of advanced age, associated with hypertension, atherosclerosis, and cardiac hypertrophy, and mostly affects the right side. ${ }^{2}{ }^{3}$ Tortuous carotid artery can be a problem during catheter insertion. In

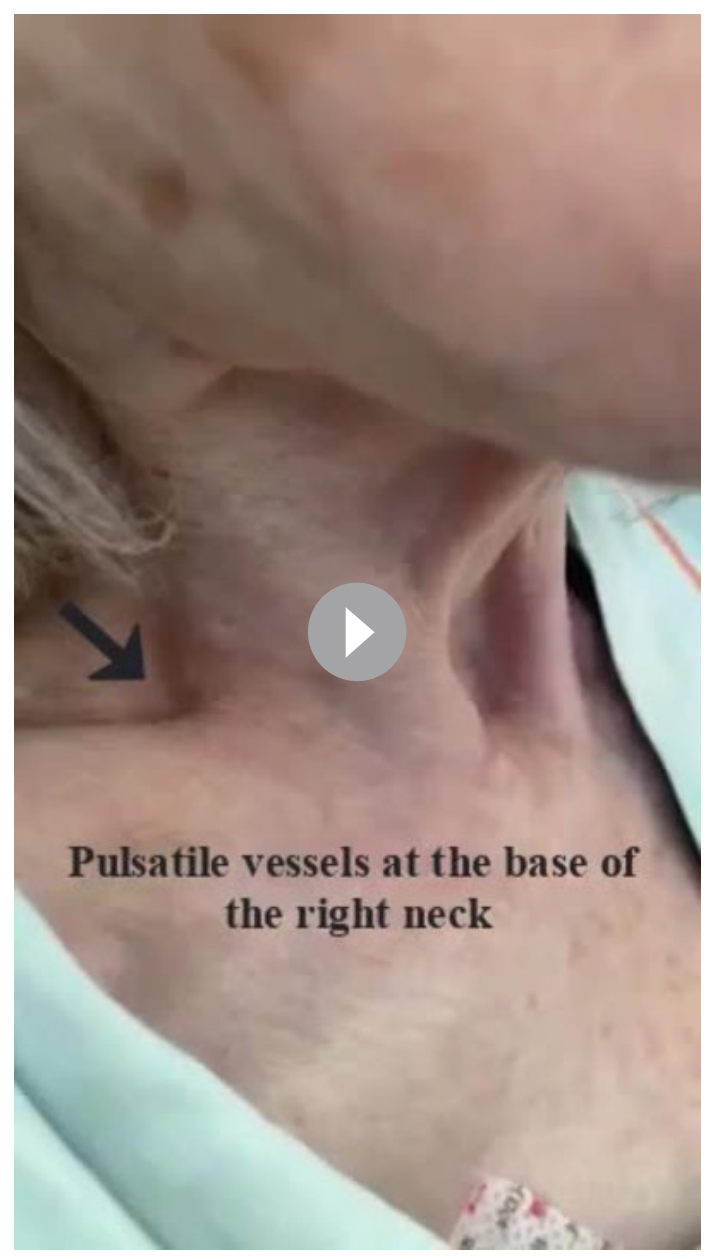

Video 1 Physical examination showing a pulsatile mass and bigeminal pulses with pulsatile vessels at the base of the right neck and prominent pulsations at the middle.
Check for updates

(C) BMJ Publishing Group Limited 2021. No commercial re-use. See rights and permissions. Published by BMJ.

To cite: Ono R, Shikino K, Kobayashi Y. BMJ Case Rep 2021;14:e242990. doi:10.1136/bcr-2021242990

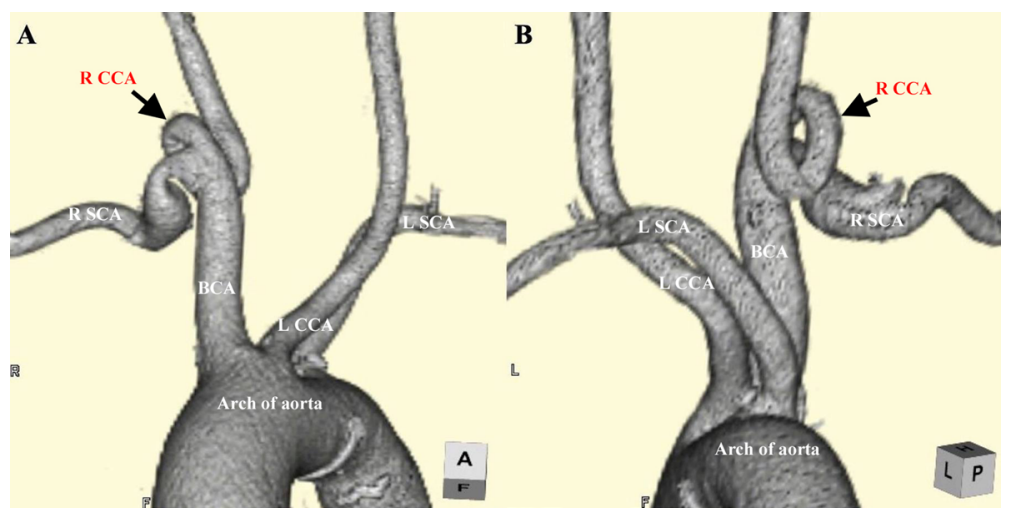

Figure 1 Preoperative contrast CT angiography showing a tortuous right common carotid artery (arrow). (A) Frontal view. (B) Posterolateral view. BCA, brachiocephalic artery; L CCA, left common carotid artery; L SCA, left subclavian artery; R CCA, right common carotid artery; R SCA, right subclavian artery. 


\section{Learning points}

- Tortuosity of the common carotid artery is seen especially in women of advanced age, associated with hypertension, atherosclerosis, and cardiac hypertrophy, and mostly affects the right side.

- Visible bigeminal pulses can be caused by tortuosity of the carotid artery.

endovascular embolisation of intracranial aneurysms, attempting to advance the guiding catheter through the tortuous artery may induce vasospasm or dissection of the tortuous vessel. ${ }^{45}$

In this case, we suspected that the common carotid artery had been looped due to the acceleration flow from severe AS straight to the CCA and left ventricular hypertrophy causing the aorta to be lifted up at right angles toward the head, resulting in visible bigeminal pulses with blood flow back and forth at the loop.

\section{Twitter Kiyoshi Shikino @K}

Contributors RO contributed to patient management, conception and design of case report; acquisition, analysis and interpretation of data, and drafting the article. $\mathrm{KS}$ and YK contributed to interpretation of data and revising the article critically. All authors gave final approval of the article and have agreed to be accountable for all aspects of the work.

Funding The authors have not declared a specific grant for this research from any funding agency in the public, commercial or not-for-profit sectors.

Competing interests None declared.

Patient consent for publication Obtained.

Provenance and peer review Not commissioned; externally peer reviewed.

\section{ORCID iDs}

Ryohei Ono http://orcid.org/0000-0002-4875-7470

Kiyoshi Shikino http://orcid.org/0000-0002-3721-3443

\section{REFERENCES}

1 Singh PK, Jangpangi G. Visible pulsus parvus et tardus in patient of aortic stenosis. BMJ Case Rep 2017;2017. doi:10.1136/bcr-2017-221034. [Epub ahead of print: $05 \mathrm{Jul}$ 2017].

2 Godin MS, Rice JC, Kerstein MD. Tortuosity of the right common carotid artery simulating aneurysm. South Med J 1988;81:1382-5.

3 Hosokawa S, Mineta H. Tortuous internal carotid artery presenting as a pharyngeal mass. J Laryngol Otol 2010;124:1033-6.

4 Takata M, Fukuda H, Kinosada M, et al. Use of simple neck extension to improve guiding catheter accessibility in tortuous cervical internal carotid artery for endovascular embolization of intracranial aneurysm: a technical note. World Neurosurg 2017;105:529-33.

5 Peeling L, Fiorella D. Balloon-assisted guide catheter positioning to overcome extreme cervical carotid tortuosity: technique and case experience. J Neurointerv Surg 2014:6:129-33.

Copyright 2021 BMJ Publishing Group. All rights reserved. For permission to reuse any of this content visit https://www.bmj.com/company/products-services/rights-and-licensing/permissions/

BMJ Case Report Fellows may re-use this article for personal use and teaching without any further permission.

Become a Fellow of BMJ Case Reports today and you can:

- Submit as many cases as you like

- Enjoy fast sympathetic peer review and rapid publication of accepted articles

- Access all the published articles

- Re-use any of the published material for personal use and teaching without further permission

Customer Service

If you have any further queries about your subscription, please contact our customer services team on +44 (0) 2071111105 or via email at support@bmj.com.

Visit casereports.bmj.com for more articles like this and to become a Fellow 